\title{
COOPERATION OF STATES IN THE FIGHT AGAINST CRIME
}

\section{Klyuev O. M.}

\section{INTRODUCTION}

The magnitude and globality of the consequences of international crimes necessitate the establishment of relations between States and international organizations to combat such negative manifestations. Over the entire history of cooperation between subjects of international law in combating crime, a fairly large body of international legal norms, principles and mechanisms for preventing, combating, suppressing and investigating international crimes has accumulated.

The process of establishing cooperation in combating international crimes actually begins with the period of origin of relations between the first developed States, when the first bilateral treaties on extradition of criminals were concluded. In the future, the development of international relations in the fight against crime actually takes place in the context of the development of international law. Each historical period posed new challenges to the international community, required the concentration of joint efforts in solving economic, political, social problems, including the problems of combating international crimes ${ }^{1}$.

\section{The main directions and forms of international cooperation of States in the fight against crime.}

The fight against crime is one of the priority areas of international cooperation. Its growth and internationalization turned this struggle into one of the main social problems and made it necessary for States to cooperate in solving it.

The main modern directions of cooperation of States in the fight against crime are:

- joint determination of the range of generally dangerous acts requiring joint efforts to suppress them;

- mutual exchange of information on committed crimes and criminals;

- assistance in tracing criminals located on the territory of the state and their extradition to interested subjects of international law;

${ }^{1}$ Shostko Elena Combating organized crime in European countries: monograph. National law Academy of Ukraine. Yaroslav The Wise. Kharkiv: Pravo, 2009. Forty, 
- joint study of crime and methods of combating it; implementation of separate instructions on criminal procedural issues;

- conclusion of international treaties on combating certain types of international criminal acts;

- participation of States in international organizations specializing in the fight against crime.

The purpose of such cooperation is:

a) harmonization of the qualification of international crimes;

b) mutual legal assistance in criminal cases, including extradition of the offender;

c) coordination of efforts and measures to prevent and suppress crimes;

d) combating certain categories of the most dangerous crimes;

e) joint solution of certain tactical tasks of investigation (search for criminals, hiding, stolen things, etc.);

f) combating transnational crimes in certain areas of activity (transport, foreign trade);

g) ensuring the inevitability of punishment.

The objectives of international cooperation in the fight against crime are:

- interaction at the interstate level;

- formation of international coordinating bodies;

- interaction at the level of individual agencies involved in the fight against international and transnational crime;

- interaction between law enforcement agencies of neighboring regions of two or more countries.

Thus, international cooperation in the fight against crime is a comprehensive coordination of actions of sovereign States, international organizations, which are aimed at developing and coordinating measures for the prevention, disclosure of certain types of crimes and the identification, detention and transfer of offenders to justice, as well as the definition of goals and objectives to minimize transnational and intra-national illegal acts.

Based on the above, it can be stated that the forms of international cooperation in the fight against crime are:

- coordination of actions to combat crime (exchange of information);

- signing of treaties on combating international crimes and crimes of an international character;

- legal assistance in criminal cases;

- carrying out operational search activities;

- conducting investigative actions;

- crime prevention; 
- joint measures to suppress criminal actions and bring perpetrators to

International cooperation of States in this important area is based on a system of certain criteria, standards, that is, international principles that determine the essence of the organization and activities of States and international organizations in the fight against international criminal acts.

In accordance with article 2, paragraph 4, of the UN Charter, "all UN members shall refrain in their international relations from the threat or use of force...". The duty of non-use of force applies to all States and is the basis for cooperation between States in various fields, including the fight against crime. The normative content of this principle can be stated in the following main provisions:

- Cooperation between States in the fight against crime should be based on a voluntary basis, without any coercion by force or threat of force;

- Problems arising from cooperation in the field of criminal justice cannot be used for the unjustified direct or indirect use of force or threat of force.

The UN Charter provides for only two exceptional cases in which armed force may be used: in self-defense (article 51) and by decision of the UN Security Council in the event of a threat to the peace, breach of the peace or act of aggression (articles 39 and 42).

Feature of the principle of peaceful settlement of international disputes is a wide range of means of peaceful settlement of disputes, as the UN Charter gives the parties freedom of choice such peaceful means as negotiation, mediation, conciliation, arbitration, trial, appeal to regional bodies and the like. When resolving a dispute in the field of criminal justice, States have the right to independently choose the method of its peaceful solution, contained, as a rule, in the texts of the Treaty ${ }^{3}$.

The arbitration method of dispute resolution is provided in particular: the Convention on laundering, search, seizure and confiscation of proceeds from crime 1980, the Convention for the suppression of unlawful acts against the safety of civil aviation 1871, the UN Convention for the suppression of illicit traffic in narcotic drugs and psychotropic substances (19 December 1988).

In accordance with the principle of non-interference in internal Affairs, no state or group of States has the right to interfere in the internal Affairs of

${ }^{2}$ Kutsevich Maxim criminal liability for ecocide: international and national aspects: monograph / M. Kutsevich; Kyiv national University. Of Taras Shevchenko. Kyiv: Yuridichna Dumka, 2009. 332 p.

${ }^{3}$ Al-Batran Khaled Regulatory framework for countering international terrorism within the framework of the Organization of Islamic Cooperation: abstract. dis. ... Yuri. Sciences: 12.00.11. NATs. UN-t odes. Yuri. Acad. Odessa, 2012.17 p. 
any state (article 2, paragraph 7 , of the UN Charter). We emphasize that the fight against crime is a matter of internal competence of the state. Based on this and guided by the universally recognized principle of non-interference, the following main provisions of the application of this principle in the fight against crime can be distinguished:

- States independently determine specific areas of cooperation, as well as partners of cooperation in the fight against crime. This provision is embodied in the fact that the state has the right to independently conclude treaties on legal assistance, as well as agreements on combating certain types of crimes, to join international organizations dealing with crime;

- States are free to determine the scope of cooperation. This provision is reflected in practice by making reservations to the relevant treaties, as well as by determining the forms of participation in international conferences, seminars devoted to the fight against crime;

- When applying the rules of international law, no one can interfere in the internal Affairs of other States. It is this warning that determines the Advisory nature of the UN resolutions and it's International Congress on combating crime and Interpol decisions;

- When concluding treaties against crime, all procedural issues are resolved only in accordance with the domestic legislation of the state. Criminal prosecution is carried out based on national substantive and procedural law and cases are considered by the competent national courts ${ }^{4}$.

Among the special principles in the field of international legal fight against crime can be identified non-extradition of citizens and political immigrants. Cooperation of States in the fight against crime is conducted only with regard to common crimes. Those charged with political crimes or prosecuted for political reasons are not subject to international treaties.

Inevitability of punishment. The legal content of this principle is that every person who has committed a crime must be punished.

Humanity. Punishment should correspond to the purpose of resocialization of the criminal. The goal is not only punishment, but also reeducation and correction.

Protection of the rights of its citizens abroad. Being outside of the state, the person does not lose communication with the state of the nationality. This principle is enshrined in the Vienna conventions on diplomatic (1961) and consular (1963) relations.

\footnotetext{
${ }^{4}$ Chornous Julia Theory and practice of forensic support of pre-trial investigation in cases of crimes of international character: monograph. NATs. Acad. EXT. cases'. Kiev: SKIF, 2012. $447 \mathrm{PP}$.
} 
International legal norms in the field of international cooperation in the fight against crime are:

- multilateral conventions for the fight against international crimes and crimes of an international character;

- treaties on legal assistance in criminal cases;

- treaties regulating the activities of relevant international organizations.

These include, for example, the international Convention of 14 December 1973. On the prevention and punishment of crimes against internationally protected persons, including diplomatic agents, the Convention on the non-application of the Statute of limitations to war crimes and crimes against humanity of 26 November 1968, the Convention on the laundering, detection, seizure and confiscation of the proceeds of crime (Strasbourg, 8 November 1990), etc.

The CIS countries have an Agreement on cooperation in combating economic crimes (Moscow, April 12, 1996), a Decision on joint measures to combat organized crime and other dangerous types of crimes on the territory of the CIS member States (Moscow, March 12, 1993), and others ${ }^{5}$.

Cooperation of States in the fight against crime is carried out on a multilateral (within the framework of international organizations) and bilateral basis. Thus, the sessions of the General Assembly and ECOSOC deal with various issues of combating crime. The UN Congresses on crime prevention are regularly convened (once every 5 years); the UN Committee on crime prevention and control meets once every 2 years; the office for crime prevention and criminal justice of the UN Secretariat is constantly functioning.

Bilateral agreements set out more specific forms of cooperation in combating certain types of crimes.

\section{Legal basis of cooperation in the fight against certain types of crimes}

We already know from the previous topics of the training course "International law" that an international offence is an act or omission of a subject of international law that violates the norms of international law and international obligations of that subject and causes material or non - material damage to another subject or group of subjects of international law or to the international community as a whole.

\footnotetext{
${ }^{5}$ International police encyclopedia: a conceptual framework. Conceptual approach. Theory and practice: In 10 vols. edited by Y. Rymarenko [and others], NAT. Acad. EXT. Affairs of Ukraine, Institute of state and law. V. Koretsky NAS of Ukraine, Acad. right. Sciences of Ukraine, Acad. ruko. Federal police. Republic Of Germany, Member Of The Academy. UPR. M-VA EXT. del Grew. Fader. Kiev: Publishing house "In Jure", 2003.
} 
Thus, from a legal point of view, an international offense is a complex legal phenomenon, and has the following characteristic main features:

- international public danger;

- wrongfulness;

- causal relationship between the wrongful act and harmful consequences;

- punish ability.

International public danger is the ability of an international offence to cause or damage international relations protected by international law. The wrongfulness of the offence is due to the violation of the mandatory rules of conduct enshrined in international legal acts. Causation is an important feature of the offense, as it allows you to find out that the cause of the harm is the cause of the offense. Punish ability is a legal consequence, a natural result of the offense. In an international offense, its composition is a set of objective and subjective features, based on which the subjects of the IP bear international legal responsibility.

The structure of an international offense includes:

- the object of an international offense is certain benefits of a material or intangible nature (international law, the system of international relations, human rights and freedoms);

- the objective side of an international offense is manifested in the form of an act of the subject of international relations, which violates the relevant international legal obligations;

- the subjects of an international offence are the States as the main subjects of the IP;

- the subjective side of the international offence consists in the relation of the subject of the MP to the act committed by him and its consequences and manifests itself in the form of guilt.

In modern international practice and doctrine, there are three types of international offenses, determined by the subject and subjective side of the composition of such offenses:

1. International crimes;

2. Crimes of an international character;

3. Other international offences (international torts) ${ }^{6}$.

International crimes are crimes that violate international obligations, which are fundamental to the vital interests of the international community, and are considered crimes by the international community as a whole

\footnotetext{
${ }^{6}$ Mironova V. problems of criminal responsibility for violation of laws and customs of war: monograph. Acad. right. Sciences of Ukraine. Kharkiv: Pravo, 2007. 152 p.
} 
(infringe on international peace and security, threaten the foundations of international law and order).

International crimes include:

a) war crimes;

b) crimes against peace and humanity (humanity);

c) aggression; genocide, ecocide.

The fight against these crimes is the competence of the UN Security Council, which bears the primary responsibility for the maintenance of international peace and security and acts on behalf of all UN member States. The subjects of international crimes are, first, States, as well as individuals acting on his behalf and personally committing such crimes. The international legal acts that establish the legal basis for combating international crimes are: the Convention on the prevention and punishment of genocide of 9 December 1948, genocide refers to acts committed with the intention to completely or partially destroy any national, ethnic, racial or religious group of people; genocide manifests itself in four forms -1 . Physical destruction, 2. - Socioeconomic genocide, 3. - Biological (deprivation of motherhood), 4. - National-cultural.); UN General Assembly resolution "on extradition and punishment of war criminals" of 13 February 1946; Convention on the nonapplication of the Statute of limitations to war crimes and crimes against humanity of 26 November 1968 and the like.

Crimes of international character on object of encroachment and degree of public danger differ from the international crimes. These are offences committed by individuals or groups of persons that infringe not only on the national but also on the international legal order, posing a public danger to two, several or all States, as well as international organizations.

These include:

- terrorism;

- distribution and trafficking in drugs;

- counterfeiting of banknotes and their sale (counterfeiting of banknotes);

- piracy;

- hostage-taking;

- computer crimes;

- human trafficking;

- hijacking of aircraft and the like.

The cooperation of States in combating crimes of an international character is regulated mainly by multilateral agreements (conventions), each of which is devoted to a specific crime. Conventions generally contain:

a) a normative definition of the offence; 
b) an obligation on the part of the state party to enshrine the Convention in national law (implementation);

c) an obligation on the part of States parties to extend their jurisdiction to the offences concerned.

In particular such international legal acts governing the legal framework for cooperation in combating international crimes are: Montreal Convention for the suppression of unlawful acts against the safety of civil aviation of 23 September 1971; Convention for the suppression of unlawful acts against the safety of Maritime navigation, 10 March 1988; international Convention against the taking of hostages of 17 December 1979; the UN Convention against illicit traffic in narcotic drugs and psychotropic substances of 19 December 1988.

International torts are defined on a residual basis; they include offences that are not included in the first two groups. These include:

- violation by the state of its unilateral obligations;

- failure to comply with the decisions of international courts and arbitration;

- violation by the state of Treaty obligations, are not of primary importance.

In the modern city, shadowy interregional and transnational criminal structures have formed and are gaining momentum, which commit unprecedented theft of money and material values from economic entities, receive super profits from socially violent crimes, such as illegal trade in Antiques, weapons, people, cars, drug and porn business (drug trafficking is 500 billion US dollars). Among the most dangerous manifestations of transnational criminal groups are the following:

1. International terrorism.

2. Committing a series of the most dangerous crimes (this is the Commission of custom theft, murder, robbery) and the return of criminals to their countries.

3. Legalization of criminal proceeds (purchase of enterprises, shares, etc.).

4. Computer criminal operations with money on accounts of domestic and foreign banks. Penetration into databases of confidential information.

5. Forgery of money and documents.

6. Evasion from payment of the established taxes.

7. Counteraction to investigation of crimes (counteraction to extradition).

8. Crimes against intellectual property.

9. Price manipulation on international and national exchanges.

10. Credit card fraud. 


\section{Environmental crimes ${ }^{7}$.}

Terrorism has become an integral part of the world's political and economic processes and poses an increasing threat to public and national security. From solitary manifestations, it has become a mass phenomenon. Modern terrorism takes the form of:

1) international terrorism (terrorist acts of international scale);

2) domestic political terrorism;

3) criminal terrorism, from mercenary motives;

4) state terrorism.

The very word "terror" is borrowed from Latin and means "fear", "horror". Terrorism is a method or achievement whose fundamental basis is the use or threat of violence. Violence is not the primary goal of terrorism, as opposed to a simple deliberate political assassination. A terrorist act, first, serves as a kind of message, a sign.

One of the most serious and most dangerous international crimes is international terrorism, which is characterized by the following features:

a) the preparation of the crime is in the territory of one state, and is carried out on the territory of another state;

b) committed a crime on the territory of one state, the terrorist, as a rule, is hiding on the territory of another state (the question of extradition).

Acts of international terrorism include cruelty, murder, hostage-taking, hijacking, torture or threats of torture, for political purposes when directed:

1. In respect of any foreign government, international organization or their representatives;

2. In respect of any citizen of a foreign state, only for being a citizen of that state.

3. When such acts are committed by a person crossing the state border of the country that requires his extradition.

After the Second world war, the problem of combating terrorism is dealt with by the UN. Thus, on 14 December 1973, the Convention on the prevention and punishment of crimes against internationally protected persons, including diplomatic agents, was adopted. The persons referred to in the Convention include:

- the head of state, the Minister of foreign Affairs (during their stay in a foreign state);

- representatives of international organizations, diplomatic agents.

${ }^{7}$ International legal assistance and cooperation in criminal proceedings of Ukraine: ZB. dock.: In 2 h. / way. I. Kogutich; LNU. Of Ivan Franko. Department of criminal procedure and criminalistics. Lviv, Triada plus, 2004 . Part 1. 2004. 940 p. 
States parties to the Convention have undertaken to cooperate in the prevention of crimes and to provide assistance and assistance in the investigation and punishment of crimes.

The European Council adopted the Convention for the suppression of terrorism in 1976, which regulates two categories of offences:

a) acts which States recognize as criminal by virtue of their participation in the Convention (illegal seizure of aircraft, attempt on the life and freedom of persons entitled to international protection, taking hostages and arbitrary deprivation of liberty, etc.);

b) acts which are recognized as criminal at the discretion of States (acts of violence, which are an attempt on the life and freedom of individuals; serious actions against property and creating a danger to people).

Distribution and drug trafficking is a crime that infringes not only on the life and health of the individual, but also at undermining the country's economy, foreign economic ties between the two countries, for their peaceful cooperation. In 1961, a single Convention on narcotic substances was signed, in 1971 - the Convention on psychotropic substances, and in 1988 - the UN Convention against illicit traffic in narcotic substances and psychotropic substances.

Under these conventions, the production, possession and distribution of narcotic and psychotropic substances, as well as their sale, purchase, import and export, are criminal offences. The fight against the proliferation and trafficking of drugs is an internal matter for each state, most of which have adopted national laws providing for severe penalties. Each state may establish its jurisdiction when the alleged offender is in its territory (art. 4). The 1988 Convention regulates in detail questions of mutual legal assistance in investigation, in criminal prosecution and trial of the corresponding offenses (art. 7).

The main international bodies exercising control over narcotic and psychotropic substances are:

The Commission on narcotic substances (CNS), which determines the list of narcotic substances to be controlled; makes recommendations for scientific research; promotes the implementation of international agreements and drafts new agreements, etc.;

The international narcotics control Board (INCB), composed of 13 experts elected by ECOSOC in their personal capacity for a five-year term, monitors countries 'compliance with drug treaties; requests States' annual production, consumption, import and export of drugs; monitors drug trafficking, etc.

Counterfeiting and distribution of banknotes is an international crime. The elimination of this crime requires the efforts of many States. In 1929, 
the Convention for the suppression of counterfeiting of banknotes was signed, according to which States undertook to prosecute those who either moonlights, falsifies banknotes, distributes counterfeit signs, participates in the manufacture or sale of other items intended for counterfeiting. Persons are brought to responsibility regardless of what country they produce counterfeit banknotes. The Convention contains a provision on the extradition of criminals to the state concerned.

Human trafficking is a serious crime. This crime covers the slave trade, trafficking in women (inducement to prostitution) and children. The most important international instruments prohibiting the trade in slaves are the slavery Convention of 1956, the Supplementary Convention on the abolition of slavery, the slave trade, institutions and practices similar to slavery (forced labour).

In 1970, States signed the Convention on the suppression of trafficking in women, which contained the obligation of States to punish such acts as incitement to prostitution by deception, violence, threat; provided for the punishment of perpetrators and their extradition at the request of the state concerned ${ }^{8}$.

Piracy is an international crime. According to the UN Convention on the law of the sea 1982, piracy is understood as:

a) any unlawful act of violence, or any robbery committed with the crew or passengers of a ship (aircraft);

b) any act of voluntary participation in the use of a ship (aircraft) in order to carry out the above actions;

The Convention obliges all States to cooperate in the suppression of piracy on the high seas, or in any other place outside the jurisdiction of any state (art.100). Any state may seize a pirate ship (aircraft), arrest its crew, seize the property on it (article 105). The seizure of a ship for piracy may be committed only by a military or a ship by a military aircraft, consisting in the public service and specially authorized for that (article 107). No state should provide safe haven to pirate ships and their crews. Pirate vessels under any flag and with any national crew may be pursued on the high seas, captured and, in case of resistance, sunk by warships of any power. When a pirate ship is captured, its crew is punished according to the laws of the capturing state (article 105). The vessel and property are confiscated by the invading state and returned to their rightful owners.

8 Demchenko I., Soloviev A. Prevention of the spread of counterfeit drugs at the international and national level: monograph / I. Demchenko, A. Soloviev. Kiev: the new press, 2014. $128 \mathrm{~s}$. 
In order to combat the seizure of aircraft, States adopted the Convention for the suppression of unlawful seizure of aircraft at The Hague in December 1970. The Convention establishes that any person on Board an aircraft in flight who unlawfully, by violence or threat of violence, seizes that aircraft or exercises control over it commits an offence. Every state has committed itself to apply in relation to such offence with severe penalties. The main objective of the Convention is to ensure the inevitability of punishment of persons guilty of illegal seizure of aircraft. The motives for such actions are not considered a circumstance that absolves the offender from responsibility.

The Convention refers to the possibility of extradition of the offender to the state concerned and establishes that each state may consider the Convention as a basis for extradition. However, the Convention does not provide for the mandatory extradition of persons who have committed an unlawful seizure of an aircraft. The state in whose territory the offender is found, if it does not extradite him, is obliged to punish him severely in accordance with its national legislation.

The Convention also provides that the authorities of the state in whose territory the hijacked aircraft landed must return the aircraft, cargo, passengers and crew to the state concerned immediately. The provisions of the Convention should apply to all cases of unlawful seizure of aircraft, both in international traffic and in domestic flights.

Fight against illegal activities with radioactive substances. The 1980 Convention on the physical protection of nuclear material was adopted to ensure the physical protection of nuclear material used for peaceful purposes and in transit, as well as nuclear material used for peaceful purposes in use, storage and transport within a state. The Convention has Annexes I and II. Annex I defines the levels of physical protection of nuclear material in international transport. Annex II classifies nuclear materials in detail.

One of the important steps in the fight against crime is to prevent the possibility of legalization of proceeds of crime and ensure their confiscation. Ukraine is a party to several agreements providing for a Set of measures to prevent the "laundering" of criminal proceeds. These include the UN Convention against illicit traffic in narcotic drugs and psychotropic substances of 1988, the Council of Europe Convention on money laundering, detection, seizure and confiscation of proceeds from crime (Strasbourg, November 8, 1990) and a number of others.

The 1990 UN General Assembly resolution defines proceeds of crime as any property obtained or realized, directly or indirectly, because of the Commission of an offence or the value of property or other benefits derived from the Commission of an offence. 
States undertake to take all measures to confiscate the instruments of crime and illicit proceeds and, in particular, to identify and search for the valuables to be confiscated and to prevent any or all alienation of these valuables ${ }^{9}$.

Courts and other competent authorities of States parties to the Convention should have the right to seize financial or other documents (no reference to Bank secrecy is allowed; however, the requested state may require that a request for cooperation requiring the removal of Bank secrecy be confirmed by a judicial authority).

Upon receiving a request for confiscation of objects or tools, the state must present it to its competent authorities. Confiscation may be refused if:

- the legislation of the requested state does not provide for confiscation for this offence;

- there is no property that is the subject of confiscation; - the Statute of limitations has expired.

The States parties to the Convention shall designate a Central authority responsible for sending, receiving and executing requests for legal assistance in such cases and shall notify the Secretary-General of the Council of Europe thereof. As a rule, most States have such a body as the Prosecutor's office.

\section{Institute of extradition in public international law (extradition)}

The adoption by the UN international law Commission at its 43rd session in 1991 of the Code of crimes against the peace and security of humankind became an essential factor of conceptual and practical order in the process of formation of an integral and modern system of international law.

Within the framework of the studied question, the provisions of article 6 of the Code "Obligations to transfer to the court or to extradite to another state" are of undoubted scientific and practical interest. It says:

1. The state in whose territory a crime against the peace and security of mankind has been committed shall transfer it to the court or extradite it to another state.

2. If extradition is requested by more than one state, special attention shall be paid to the request of the state in whose territory the offence was committed."

The resolution of article 6 of the Code is a classic example of the application of the principle «either extradite or punish". This principle brings us to the immediate subject of our study - the institution of extradition.

\footnotetext{
${ }^{9}$ Mechanisms of law enforcement cooperation in the process of detection and investigation of crimes related to human trafficking: studies / Amer. Assoc. international initiative on the rule of law (ABA / ROLI); podgot.: Marina Elefante, Ludmila Ilkovic. Kiev, 2010. $39 \mathrm{sec}$.
} 
The importance of the institution of extradition in the implementation of international criminal justice is confirmed by the adoption without a vote (that is, by consensus) on 14 December 1990 at the 45th session of the UN General Assembly (resolution 45/116) of the model Treaty on extradition. The legal act establishes the types of offences for which extradition may be applied.

Extradition treaties perform an important function of international criminal justice ensuring the principle of inevitability of punishment for the whole range of criminal, international and international crimes.

There is no single definition of extradition. In the monograph of the scientist G. M. Valeev, extradition should be understood as an act of legal assistance based on international treaties and generally recognized norms and principles of international law, which is expressed in the transfer of the accused or convicted by the state in whose territory he is, to the state in whose territory the person committed the crime or whose citizen he is, or to the state that the victim of the crime, to bring him to criminal responsibility or to enforce the sentence.

The very term "extradition" comes from Latin and means the forcible return of this person to his sovereign.

Extradition (extradition - transfer) is a transfer from one state to another on its request or the request of the person who committed an international crime or crime of international character is suspected of committing such offence, to bring it to legal liability or coercion made against her court verdict ${ }^{10}$.

Scientific and theoretical definition-extradition should be understood as a process that is based on international treaties, generally recognized principles of international law, norms of domestic law and is associated with the provision of legal assistance by States, consisting in the transfer of a suspect, accused or convicted by the state in whose territory he is, the state in whose territory he committed a crime or a citizen of which he is, or the state that the victim of the crime, to bring him to criminal responsibility or to execute the sentence of the court.

The European Convention on extradition 1957, the first in world practice introduced a fairly complete mechanism for the implementation of the Institute of extradition (extradite) persons and a number of procedural safeguards rights of a person, which is issued to conduct the preliminary investigation or judicial proceedings with respect of the offense committed.

${ }^{10}$ Using the capabilities of the NCB Interpol in Ukraine in the fight against crime: studies. manual / V. Nekrasov [et al.]. Kyiv: KNT: SKIF, 2008. 163 p. 
A state may extradite an offender if it and another state have entered into a relevant Treaty (extradition Treaty or legal aid Treaty). In the absence of such a Treaty, the state shall, in accordance with its domestic law, decide on the extradition or non-extradition of the offender.

Extradition of criminals occurs in the presence of:

1 - legal basis (legal provisions in national law, bilateral treaties for extradition or legal assistance in criminal matters, international agreements on the fight against certain types of international crimes, international crimes);

2 - terms of issue (the act provided for by the Treaty on extradition; it is defined in the criminal law of the two States and provides for the punishment, the upper limit of which exceeds one year of imprisonment or more severe punishment; the person seems to be sentenced only for the offense; the death penalty will not be applied if it is not provided for by the laws of the issuing state).

The procedure for extradition includes:

- sending a request or petition for extradition;

- taking the offender into custody;

- negotiating extradition through diplomatic channels;

- extradition in accordance with the instructions of the competent authorities of the party, which issues in the prescribed manner with reimbursement of expenses incurred.

The issuance is not subject to:

- nationals of the requested country (private citizens) or the person is in this state, the right of asylum;

- in cases of private prosecution or political crimes (war criminals and perpetrators of crimes against humanity are not political criminals, in accordance with resolutions of the UN General Assembly);

- while committing a felony in the state of stay (pending a relevant court decision or sentence);

- if the person suffered a criminal punishment for the crime or was acquitted by the court;

- in connection with the expiration of the Statute of limitations, or the proceedings were closed on a legal basis;

- the threat of application to the offender of unlawful measures of mental or physical influence.

In international law, there are three types of extradition: - extradition of a person for criminal prosecution; - extradition of a person for the purpose of execution of punishment; - temporary extradition.

Extradition of persons for criminal prosecution or execution of punishment. 
Under legal aid treaties, a person can be extradited for any crime, not just specific crimes of an international character. The results are produced only for acts which under the laws of both parties punishable by imprisonment for a fixed term (usually over one year) or a stricter punishment (that is, under those conditions which we considered earlier).

Specific issues of extradition of criminals is regulated between the States concerned. Thus, on May 27, 1993, Ukraine and the Republic of Poland signed an Agreement on legal assistance and legal relations in civil and criminal cases, according to which the parties undertook (art.60 to extradite each other at the request of persons located in their territory, for the purpose of criminal prosecution or execution of punishment).

The extradition of a person to carry out a sentence consists of the transfer of a person who has been convicted by a foreign court and has absconded from serving a sentence, but has been detained in the territory of another state. The application for extradition shall be accompanied by a certified copy of the sentence that entered into force, certified in the appropriate manner (usually by the Ministry of justice) on the basis of which the person was convicted.

If the person in respect of whom the request for extradition is filed is brought to criminal responsibility or is serving a sentence for another crime in the territory of the requested party, his temporary extradition may be carried out at the reasonable request of the requesting party. The temporarily extradited person, after carrying out the procedural actions for which he was extradited, must be returned.

\section{International criminal police organization (Interpol)}

The international criminal police organization - Interpol (IOCP Interpol) was established on September 7, 1923 by the decision of the International police Congress, which was held in Vienna, Austria.

Today, the working body of Interpol is the General Secretariat (Lyon, France).

Interpol includes General Assembly, Executive Committee, General Secretariat, National Central Bureau, Advisers.

The General Assembly is the highest organ of the Organization. One or more delegates may represent each member. However, the delegation of each country should have only one leader appointed by the competent governing body of that country.

The functions of the General Assembly include:

- to fulfil the obligations stipulated by the Charter; define the principles of and General measures, which should contribute to the goals of the organization; to consider and approve the overall work plan, which is 
submitted to the General Secretary for the next year; to install other necessary rules; to choose individuals to perform functions under the Charter; to take decisions and make recommendations to Members on matters within its competence; determine the financial policies of the organization; consider and approve agreements with other organizations.

Only one delegate from each country has the right to vote. Decisions are taken by a simple majority of votes, except for those for which the Charter provides for a majority of $2 / 3$ of the votes.

The Executive Committee consists Of the President of the Organization, three Vice-Presidents and 9 delegates.

The General Assembly elects from among its delegates a President (for 4 years) and three Vice-Presidents (for 3 years).

The President: - presides over the sessions of the General Assembly and of the Executive Committee and direct the discussion; oversees that the operations of the Organization consistent with decisions of the General Assembly and Executive Committee; maintains constant communication with the Secretary-General of the Organization.

The Executive Committee: monitors the implementation of the decisions of the General Assembly; prepares the agenda of the sessions of the General Assembly; submits to the General Assembly a work plan and proposals as it deems appropriate; monitors the activities of the Secretary-General; exercises all powers delegated to it by the Assembly.

The permanent services of the Organization constitute its General Secretariat.

The General Secretariat implements the decisions of the General Assembly and the Executive Committee, acts as an international Centre for combating common crime; provides effective administrative management of the Organization; maintains relations with national and international bodies; prepares the necessary publications, etc.

The General Secretariat consists of the Secretary-General, specialists and administrative staff. The Secretary-General shall be nominated by the Executive Committee and approved by the General Assembly for a term of 5 years.

The Organization may consult with Advisors on scientific matters. The Executive Committee appoints advisers for a period of 3 years from among internationally known people in the field of activity that interests the Organization $^{11}$.

However, the history of this organization begins much earlier.

${ }^{11}$ Bandurka O. Interpol: international criminal police organization: sci.- pract. manual / O. Bandurka; national UN-t of internal Affairs. Kharkiv: Osnova, 2003. 323 p. 
In the late XIX - early XX century, before law enforcement agencies around the world increasingly began to appear issues of search and detention of persons who have committed crimes and hiding from criminal responsibility abroad. The realities of public life, namely the development of economic, political and social ties between States, contributed to the integration of crime at the international level. It was then that there was a need to establish an international police organization to ensure proper cooperation of law enforcement agencies of different States in the fight against international (or transnational) crime.

1889 the founding meeting of the international criminal law Union was held. The participants noted the emergence of international crime and called on the police of different countries to take concerted action to overcome it. At the same time, there were proposals to bring under police Cooperation a permanent, institutionalized base - first at the national and then at the international level.

1905 at the international conference of criminalists of the Germanspeaking countries the next attempt to unite efforts in fight against the international crime is made. At its 10th international Assembly in Hamburg, the criminologists, on the proposal of the French-speaking States, adopted a resolution confirming that the increased demand for tourism and foreign travel contributes to the emergence of new forms of international crime. Thus, joint international efforts are needed to overcome it. It was therefore planned to establish national Central bureau within police units to exchange information on international crime and to improve direct police relations.

The problems of combating international crime were discussed at many conferences and congresses: 1905. (Buenos Aires), 1909 (Madrid), 1912 (Sao Paulo) and 1913 (Washington).

In 1914, Monaco hosted the first international Congress of criminal police, represented by experts from Austria, Great Britain, Italy, Russia and France. There were four items on the agenda of the Congress:

1. Unification of the procedure for extradition of criminals;

2. International preventive anthropometry;

3. Creation of the Department for accounting of international criminal information;

4. Development of measures to speed up and simplify the arrest of criminals.

In subcommittees, police officials discussed technical issues related to the protection of police officers, the adoption of the international police code, etc.

The first section dealt with the General problems of the police. The second and third are separate issues of the work of the international police 
and peculiarities of the legislation of different countries. The participants of the forum asked the government of Monaco to take the initiative to establish international commissions in Paris to develop unified standards of identity cards and to organize a single international Bureau for the identification of international crimes. At the same time, they agreed to meet two years later in Bucharest at the Second international Congress of criminal police. However, during the First World War, not only these hopes, but all the resolutions adopted in Monaco, have sunk into oblivion.

After the First World War, the same problem was on the agenda international crime, but in a more acute form. The morality of wartime has affected-the crime rate has sharply increased, in particular, based on drug addiction and alcoholism. Therefore, the issue of combining the efforts of the criminal police against crime at the international level has acquired special relevance ${ }^{12}$.

In September 1923, the international police Congress was held in Vienna (Austria), represented by all continents except Australia. Criminologists, criminologists and diplomats attended it from Austria, Belgium, Denmark, Egypt, Greece, Italy, Latvia, Lithuania, the Netherlands, Germany, Poland, Romania, the United States of America, Turkey, Hungary, France, Czechoslovakia, Switzerland and Sweden.

One of the resolutions of the Congress established the International criminal police Commission (ICCP), with its first official headquarters in Vienna, which immediately began work on its program of action (so, September 7, 1923. considered the date of birth Of the international criminal police organization - Interpol). In 1924, the ICCP adopted a resolution on five important issues that determined the direction of development for many years to come, namely: the establishment of information offices for the collection of facts of international crime; the development of evidence systems and the international search for criminals; organization offices to identify individuals at a distance; the newspaper of the international police; the creation of the overall program to prevent and detect counterfeit banknotes and documents.

1930 ICCP developed the principles of extradition.

In March 1938, German troops occupied Austria, and 18 months later, the Second world war began. The activities of the ICCP were curtailed.

Since 1940, the chief of the German security service, Heydrich, headed the ICCP. The ICCP administration was transferred to Berlin.

${ }^{12}$ Gritsaenko L. Bodies of the European Union on fight against crime and legal bases of their cooperation with Ukraine. Bulletin of The national Academy of Prosecutor's office of Ukraine. 2012. No. 1. P. 91-95. 


\section{During the Second World War there has been no official Congress of the ICCP.}

1946 representatives of 17 States in response to the call of the Belgian government met in Brussels to re-establish the international criminal police Commission. It was decided to move its headquarters to Paris (France). 19 countries resumed their participation in the ICCP, among them Belgium, Chile, Czechoslovakia, Denmark, Egypt, France, Greece, Iran, Luxembourg, Netherlands, Norway, Poland, Portugal, Turkey, Sweden, Switzerland, Yugoslavia, United Kingdom and United States of America.

It should be noted that for the first time the word "Interpol" (as well as the modern sign - symbol of the Organization) in 1914 appeared on the pages of the "Journal de Monaco" in an article about the First international Congress of criminal police. And since July 22, 1946 is used as a Telegraph designation of the address of the headquarters in Paris.

1956 in Vienna on anniversary 25th session General Assembly ICCP adopted Charter Organizations, in UF. 1, which referred, that henceforth international Commission criminal police will be called International organization criminal police (IOCP) - Interpol. The Charter provides for cooperation at the world level, before that-the influence of the Organization extended mainly to European States. 1989 its headquarters was relocated to Lyon (France).

Consequently, three very important changes have taken place during the existence of the ICCP.

First, it has spread to the whole world because of the accession of new members.

Second: in 1956, the international criminal police Commission was renamed the international criminal police organization - Interpol.

Third, the Statute of Interpol has been adopted, which is still in force, practically unchanged.

The main tasks and goals of Interpol, according to the Charter:

- ensuring broad cooperation between the criminal police authorities concerned within the framework of the current national legislation of the member countries of Interpol and in strict accordance with the provisions of the world Declaration of human rights;

- creation and development of all necessary bodies that will be effective in combating common crime.

Under the Statute, Interpol does not engage in or interfere with activities of a political, military, religious or racial nature.

The cooperation of police authorities within Interpol is based on the actions applied by these authorities in their countries and in strict accordance 
with their national legislation. All Interpol member countries have equal rights regardless of their financial contributions.

Currently, 187 countries of the world are members of the international criminal police organization - Interpol.

The history of the Working apparatus of the Interpol Ukrbyuro.

After the Declaration of independence, Ukraine needed constant, prompt and effective international cooperation, as well as attracting advanced foreign experience for the development of its own law enforcement system and combating transnational organized crime.

Given the lack of relevant experience, the first steps in this area were not easy.

The possibility of Ukraine's accession to the international criminal police organization was studied in April 1991, when the Ukrainian Republic was part of the USSR.

Immediately after independence, at the initiative of the Ministry of internal Affairs of Ukraine, supported by the Ministry of justice, Ministry of foreign Affairs and the security Service, on behalf of the Government was submitted to the General Secretariat of Interpol on Ukraine's accession to the Organization.

Ukraine's admission to Interpol took place on 4 November 1992 at the 61st session of the Interpol General Assembly (Dakar, Senegal). From Ukraine, the session was attended by a delegation, which included the first Deputy Minister of internal Affairs of Ukraine Vladimir Mikhailovich Korneychuk and chief Of staff of the Ministry of internal Affairs Alexander Mikhailovich Ishchenko.

After gaining membership in Interpol, there was an urgent need to create a unit that would directly provide the function of the national Central Bureau of Interpol in Ukraine. To this end, the interior Ministry created a temporary working group to interact with Interpol, the head of which was appointed Pyotr Melnik ${ }^{13}$.

The working group included employees of the Ministry Grigory Stelmakh, Igor Limarchenko, Oleg Kaplin, Zinaida Verbenko and others.

These people have done a tremendous job and in fact created the Foundation for the further development of the Ukrainian Bureau of Interpol.

In addition, already on March 25, 1993, according to the obligations provided by the membership of the state in the Organization, by the decision of the government of Ukraine the national Central Bureau of Interpol was

\footnotetext{
${ }^{13}$ Mironova V. problems of criminal responsibility for violation of laws and customs of war: monograph. Acad. right. Sciences of Ukraine. Kharkiv: Pravo, 2007. 152 p.
} 
created. On this day, the "Regulation on the National Central Bureau of Interpol" was also approved.

Participation of employees of Ukrburo together with representatives of law enforcement agencies of Ukraine in international events of IOCPInterpol made possible the exchange of experience with foreign colleagues in the fight against crime.

The national Central Bureau of Interpol (Ukrburo Interpol) represents Ukraine in Interpol and is the center of coordination of interaction of law enforcement agencies of the country with the competent authorities of foreign countries in the fight against crime, which has a transnational character or goes beyond the country.

The powers of the Ukrburo of Interpol are assigned to the Ministry of internal Affairs, within which the working apparatus of the Bureau is created.

The main objectives of Ukrbyuro of the Interpol are: - coordination of activities of law enforcement agencies in the fight against crime, which is transnational in nature or outside the country; - ensuring interaction with the General Secretariat and the relevant bodies of the member States of Interpol in the fight against crime; - assessment of the level of acceptance in Ukraine of crime having a transnational character, and threats of criminal activity of citizens of Ukraine abroad.

In order to determine the evidence-based state policy against crime and to develop recommendations and proposals to combat crime that has a transnational nature or goes beyond the country, the Interpol Ukrburo may turn to advisers who perform exclusively Advisory functions on a contractual basis.

The Ministry of internal Affairs in coordination with the Ministry of justice and the security Service determines the composition of advisers.

The working unit of Ukrbyuro Interpol is an independent structural subdivision of the Central apparatus of the interior Ministry, headed by its Director appointed by the President. The Minister of internal Affairs approves the structure and staff of the working apparatus.

According to the legislation of Ukraine, the activity of the Ukrainian Bureau of Interpol consists in the organization of information support of criminal and operational-search cases, which are in the production of law enforcement agencies of Ukraine and foreign countries.

Of Ukrbyuro of Interpol, in particular, provides:

- exchange of information between law enforcement agencies of Ukraine and foreign States during the proceedings on the relevant criminal and operational-search cases in order to organize the necessary checks and operational-search activities; 
- international search for accused and defendants who are hiding from law enforcement agencies in order to evade criminal responsibility and are on the state or interstate wanted list; organizes the extradition of such persons.;

- search for missing persons, search for victims of human trafficking, search for stolen vehicles, cultural property and Antiques, identification of persons and unidentified corpses, etc.;

- exchange of analytical and statistical information on the fight against crime and the organization of law enforcement agencies.

Department of international investigation and extradition.

The Department of international investigation and investigation support of the working apparatus of the Ukrburo Interpol since 2008 includes the Department of international investigation and extradition, which currently has seven certified employees. The main task of this unit follows from its name, that is, the organization of international search on the territory of all member countries of Interpol, as well as the extradition of criminals from Ukraine and to Ukraine. Actual for the specified division also is activity on placement of cards in the international information system of Interpol ASF, and also accumulation, systematization and the analysis of information of criminal character concerning physical and legal persons, criminal groups, tendencies of development of transnational crime. Collection and analysis of information concerning persons and organized criminal groups involved in the Commission of serious and especially serious crimes in order to enter this information into the databases of the Working apparatus and the General Secretariat, as well as initiating a ban on their entry into the territory of Ukraine and expulsion from its borders.

Besides the already noted the staff of the Department of international fugitives and extraditions in their daily work, study and generalize the advanced world experience in the organization of the international investigation and extradition, participate in discussion forums on issues related to the competence of the Department, and provide practical assistance to law enforcement agencies of Ukraine and other member countries of Interpol in investigating and solving transnational crimes ordinary orientation.

The Department of international investigation and extradition of the Interpol Ukrburo interacts with law enforcement agencies of Ukraine, Central and local government authorities, governing bodies and divisions of Interpol, law enforcement agencies of foreign countries in the performance of its tasks.

International agreements on extradition and mutual legal assistance play an important role in carrying out the tasks assigned to the international 
investigation and extradition division. These agreements are an effective means of cooperation in the fight against criminal offences.

At the end of 1994, according to the plan of technical modernization of the General Secretariat of Interpol, Ukrburo was equipped with a modern communication system, which significantly improved the exchange of information between Ukrainian law enforcement officers and foreign colleagues.

Important events in the early formation of Ukrbyuro Interpol were the visits to Ukraine of high-ranking officials of the International criminal police organization - in January 1996, the President of Interpol Mr. Bourne Erickson (representative of police of Sweden) and in May of the same year Secretary-General Mr. Raymond Kendall (police UK).

Ukrburo Interpol in the period from 1996 to 2009.

During this time, the heads of the division were Viktor Radetsky (1996-2001), Alexander Chemenko (2001-2002), Nikolai Dzhiga (2002-2003), Stanislav Denisyuk (2003), Viktor Zubchuk (2003-2004), Anatoly Slipchenko (2004-2005), Kirill Kulikov (2005-2007), Rostislav Vergeles (2007), Vasily Vladimirovich nevolya (2007 - by t/h).

An important stage of formation and development of Ukrburo Interpol was the period 1997-2000. In particular, in 1998 the staff of the Bureau was expanded, which allowed creating another part. Since then, the unit has been operating around the clock.

At that time, the systematized data banks of the Interpol Ukrburo were created, normative documents regulating the order of international cooperation between law enforcement agencies of Ukraine and Interpol were adopted, including: Manual on the use of law enforcement capabilities of National Central Bureau of Interpol in Ukraine in the prevention, disclosure and investigation of crimes approved by joint order of the Ministry of internal Affairs of Ukraine, General Prosecutor's office of Ukraine, security Service of Ukraine, State Committee for state border protection of Ukraine, State customs service of Ukraine, State tax administration of Ukraine from January 9, 1997 № 3/1/2/5/2/2.

In 2003, Mr. Ronald Kenneth noble, Secretary General of Interpol, visited Ukraine and held working meetings with the President of Ukraine, the interior Ministry and other law enforcement agencies of Ukraine.

The negotiations gave a significant impetus to the development of international law enforcement cooperation through Interpol channels. Firstly, the working apparatus of the Interpol Ukrburo was connected to the new telecommunication system Interpol I-24/7, secondly, the Secretary General raised the issue of the European Commission to provide international technical assistance to the Ukrainian division of Interpol, thirdly, the high 
assessment of the activities of the Interpol Ukrburo by the first person of the Organization in the future became a prerequisite for closer cooperation of law enforcement agencies of Ukraine with the Interpol General Secretariat.

Outstanding event.

Since 2003, cooperation between Ukrburo Interpol and the General Secretariat Of the organization has reached a new level. In particular, according to the agreement between the interior Ministry and the General Secretariat of Interpol, according to the relevant decree of the President and the Cabinet of Ministers of Ukraine had resolved the question about the direction of the representative of the Ministry of internal Affairs of Ukraine the General Secretariat of Interpol.

In 2004-2008, a number of Interpol international events were also held in Ukraine, in particular: the 33rd Interpol European regional conference (May 2004); the Interpol international seminar on countering bioterrorism (November 2006); the first Interpol international seminar on the use of DNA research in law enforcement (October 2008).

In addition, in the period from 2006 to 2008, the interior Ministry has taken measures on implementation of the international technical assistance project of the European Commission TACIS project "International cooperation in criminal matters, via Interpol". The budget of this project was 990 thousand euros.

According to the tripartite agreement, technical assistance was provided at the expense of the European Commission, the implementation of the project was carried out directly by the General Secretariat of Interpol, and the Ministry of internal Affairs of Ukraine was the recipient of this assistance.

Its main task was to comprehensively improve the activities of the Ukrainian Bureau of Interpol and international cooperation of law enforcement agencies of Ukraine within Interpol as a whole.

For two years, the project funds were:

- organized the participation of employees of the Working apparatus of Interpol Ukrburo and other departments of the Ministry of internal Affairs in international events held by Interpol;

- significantly updated the Park of computer and organizational equipment in the Working apparatus of Ukrburo Interpol;

- set up and equipped in the Kiev national University of internal Affairs classroom for training law enforcement officers of Ukraine and foreign countries to work with Interpol data banks, as well as the use of other Interpol capabilities in everyday activities in the detection and investigation of crimes. 
The peculiarity of the newly created classroom is that the computer equipment installed in it has direct access to the Interpol data banks located in the General Secretariat of the Organization through the Interpol - I-24/7 telecommunication system.

Today, the working apparatus of the Ukrburo of Interpol is a wellorganized, modernly equipped unit that is able to provide effective assistance to law enforcement agencies in conducting operational search and other activities abroad in cases of transnational crimes of a common criminal and economic orientation, in particular, human trafficking, money laundering, international drug trafficking, terrorism, cybercrime, in organizing an international search of persons and obtaining information from the data banks of the General Secretariat of Interpol, law enforcement agencies of other countries ${ }^{14}$.

With Ukrburo Interpol actively interact not only units of internal Affairs, and the Prosecutor General's office, security Service, State tax administration, state customs service, state border service, foreign intelligence Service.

However, the unit does not stand still and continues to develop. In particular, work is underway to improve the regulatory support for international law enforcement cooperation through Interpol channels: draft new regulations or amendments to existing documents are being prepared. Work is also continuing to improve the technical component in the activities of the unit, including the improvement of existing in Ukrburo electronic data banks, electronic document management and so on. In addition, in 2009, it was planned, together with the Kiev University of internal Affairs, to prepare and implement a training course for students of the University and practitioners of the internal Affairs bodies in working with Interpol data banks and using other opportunities of the Organization in everyday work during the detection and investigation of crimes.

\section{CONCLUSIONS}

Thus, international cooperation of States in the fight against crime is the cooperation of States aimed at the development and coordination of measures for the prevention, detection of crimes and treatment of offenders, as well as the development of comprehensive goals and objectives to minimize transnational and domestic illegal acts. It develops at three levels:

${ }^{14}$ Demchenko I., Soloviev A. Prevention of the spread of counterfeit drugs at the international and national level: monograph / I. Demchenko, A. Soloviev. Kiev: the new press, 2014. $128 \mathrm{~s}$. 
the level of bilateral cooperation between States; regional level; cooperation at the universal (global) level.

\section{SUMMARY}

When studying the topic and preparing for the lesson, it should be noted that the duty of cooperation of States directly follows from the UN Charter. It must be remembered that a successful fight against crime, especially that of an international nature, requires the coordination of the efforts of many States. It should be noted that the fight against crime is one of the most important internal functions of the state. An important point is that the internationalization of crime, the need to unite the efforts of States in the fight against it has given rise to a trend towards the internationalization of criminal law.

\section{REFERENCES}

1. Al-Batran Khaled Regulatory framework for countering international terrorism within the framework of the Organization of Islamic Cooperation: abstract. dis. ... Yuri. Sciences: 12.00.11. NATs. UN-t odes. Yuri. Acad. Odessa, $2012.17 \mathrm{p}$.

2. Bakay Martha Implementation of the provisions of the "anticorruption" conventions in the domestic criminal legislation: abstract. dis. ... Cand. Yuri. Sciences: 12.00.08. Kiev. NATs. UN-t im. Of Taras Shevchenko. Kiev, 2013.19 p.

3. Bandurka O. Interpol: international criminal police organization: sci.pract. manual / O. Bandurka; national UN-t of internal Affairs. Kharkiv: Osnova, 2003. $323 \mathrm{p}$.

4. Belotsky S. international legal regulation of peacekeeping: studies. benefit. for students. UNIVERSITY / S. Belotsky; Kiev. NATs. UN-t im. Of Taras Shevchenko. Kiev: Kiev. UNT, 2012. 287 p.

5. Using the capabilities of the NCB Interpol in Ukraine in the fight against crime: studies. manual / V. Nekrasov [et al.]. Kyiv: KNT: SKIF, 2008. $163 \mathrm{p}$.

6. Voronenko V. Problems of international cooperation in the sphere of countering nuclear proliferation and nuclear terrorism. Archive of clinical medicine. 2011. No. 2. P. 84-90.

7. Garbisa Dmitry International legal framework against corruption : author. dis. ... Cand. Yuri. Sciences: 12.00.11. NATs. Yuri. UN-t im. Yaroslav The Wise. Kharkiv, 2015. 22 sec.

8. Gritsaenko L. Bodies of the European Union on fight against crime and legal bases of their cooperation with Ukraine. Bulletin of The national Academy of Prosecutor's office of Ukraine. 2012. No. 1. P. 91-95. 
9. Demchenko I., Soloviev A. Prevention of the spread of counterfeit drugs at the international and national level: monograph / I. Demchenko, A. Soloviev. Kiev: the new press, 2014. $128 \mathrm{~s}$.

10. Information technologies of fight against terrorism: materials of Sciences.- pract. Conf. Kiev, 15 Jul. 2012 / Acad. no. of education of Ukraine, Global acad. of alled leadership, Acad. of open society security. Kyiv: Lipan O. vid., 2012. 91 p.

11. Kulichenko O. Interpol. Evolution of the structure and activities: monograph / O. Kulichenko. View. 1-E. Kirovograd: RVV KDPU im. Vladimir Vinnichenko, 2013. 175 p.

12. Kutsevich Maxim criminal liability for ecocide: international and national aspects: monograph / M. Kutsevich; Kyiv national University. Of Taras Shevchenko. Kyiv: Yuridichna Dumka, 2009. 332 p.

13. Makarukha S. Legal bases of activity of the European Union in the sphere of ensuring space of freedom, safety and justice: monograph / S. Makarukha; Kiev. NATs. UN-t im. T. Shevchenko. Lviv: Astrolabe, 2011. 543.

14. Matviychuk V. counteraction to crime and adaptation of criminal legislation and law of Ukraine to the legislation and law of the European Union: monograph / V. Matviychuk et al.; ed. Acad. UPR. Kyiv: UNIVERSITY "national Academy of management", 2014. $551 \mathrm{~s}$.

15. Mechanisms of law enforcement cooperation in the process of detection and investigation of crimes related to human trafficking: studies / Amer. Assoc. international initiative on the rule of law (ABA / ROLI); podgot.: Marina Elefante, Ludmila Ilkovic. Kiev, 2010. 39 sec.

16. Mikievich M. international legal framework for combating transnational crime within the European Union. Scientific Bulletin of Lviv state University of internal Affairs. 2008. No. 2. P. 1-8.

17. Mironova V. problems of criminal responsibility for violation of laws and customs of war: monograph. Acad. right. Sciences of Ukraine. Kharkiv: Pravo, 2007. $152 \mathrm{p}$.

18. International police encyclopedia: a conceptual framework. Conceptual approach. Theory and practice: In 10 vols. edited by Y. Rymarenko [and others], NAT. Acad. EXT. Affairs of Ukraine, Institute of state and law. V. Koretsky NAS of Ukraine, Acad. right. Sciences of Ukraine, Acad. ruko. Federal police. Republic Of Germany, Member Of The Academy. UPR. M-VA EXT. del Grew. Fader. Kiev: Publishing house "In Jure", 2003.

19. International legal assistance and cooperation in criminal proceedings of Ukraine: ZB. dock.: In 2 h. / way. I. Kogutich; LNU. Of Ivan Franko. 
Department of criminal procedure and criminalistics. Lviv, Triada plus, 2004. Part 1. 2004. 940 p.

20. Sergey Petrashko Fight against corruption: international dimension and national practice: monograph / Sergey Petrashko; In-t legislation of the Verkhovna Rada of Ukraine. Kyiv: Institute of legislation of the Verkhovna Rada of Ukraine, 2014. 231 p.

21. Combating drug-related crime: domestic and international experience of cooperation of law enforcement and judicial authorities. Bekämpfung der Drogenkriminalität. Zusammenarbeit von Polizei und Justiz: proceedings of the Ukr.-he. sciences'.- pract. conf., M. Donetsk, 26-27. 2011 / Verkhovna Rada of Ukraine, com. on issues legislators. sabesp. no. active., Donets. Yuri. Institute of Lugano. state University EXT. cases to them. E.O. Didorenko, G. zaydel Foundation. Donetsk: DUI of LDUS, 2011. $307 \mathrm{p}$.

22. Chornous Julia Theory and practice of forensic support of pre-trial investigation in cases of crimes of international character: monograph. NATs. Acad. EXT. cases'. Kiev: SKIF, 2012. 447 p.

23. Shostko Elena Combating organized crime in European countries: monograph. National law Academy of Ukraine. Yaroslav The Wise. Kharkiv: Pravo, 2009. 44 p.

\section{Information about the author: Klyuev O. M., Doctor of Law, Professor, of the Ministry of Justice of Ukraine} Director of the Kharkiv Scientific Research Institute of Forensic Examinations N.A. Prof. M. S. Bocarius 8-A, 49 Zolochivska str., Kharkiv, 61177, Ukraine 